J. Amer. Soc. Hort. Sci. 116(5):917-922. 1991.

\title{
Regeneration from Sweetpotato Protoplasts and Assessment of Growth Conditions for Flow-sorting of Fusion Mixtures
}

\author{
Srini C. Perera and Peggy Ozias-Akins \\ Department of Horticulture, University of Georgia, Coastal Plain Experiment Station, Tifton, \\ GA 31793 \\ Additional index words. flow cytometry, Ipomoea batatas, tissue culture
}

\begin{abstract}
Petiole protoplasts of the sweetpotato [Ipomoea batatas (L.) Lam.] cultivars Red Jewel and Georgia Jet formed cell walls within 24 hours and divided in 2 to 3 days. Pretreating enzyme solutions with activated charcoal increased the viability and division frequency of protoplasts. Culture of protoplast-donor plants in a medium containing STS did not affect plant growth, protoplasm yield, or viability, but did increase the division frequency. Culture of protoplasts for 24 hours in a medium containing DB, a cell wall synthesis inhibitor, or staining of protoplasts with FDA did not significantly affect division frequency. The division frequency of protoplasts cultured in liquid medium was significantly higher than that of protoplasts cultured in agarose-solidified medium. Cell cycle analysis of petioles and freshly isolated protoplasts showed that the latter has a significantly higher proportion of nuclei in $G_{1}$ phase. Protoplasts did not initiate DNA synthesis or mitosis within the first 24 hours of culture. Low-frequency regeneration of shoots from protoplast-derived callus was accomplished on MS medium containing $1.0 \mathrm{mg}$ ldnetin/liter when preceded by MS medium modified to contain only (in mg·liter ${ }^{-1}$ ) $800 \mathrm{NH}_{4} \mathrm{NO}_{3}, 1400 \mathrm{KNO}_{3}, 0.5$ 2,4-D, 0.5 kinetin, and 1.0 ABA. Roots produced from protoplast-derived callus formed adventitious shoots after 4 weeks on MS medium containing $2 \%$ sucrose, $0.02 \mathrm{mg}$ kinetin/liter and $\mathbf{0 . 2 \%}$ Gelrite. Secondary shoot formation from regenerated roots will be a more effective means of obtaining plants from protoplasts than direct shoot regeneration from callus. Chemical names used: silver thiosulfate (STS): 2.6-dichlorobenzonitrile (DB); fluorescein diacetate-(F円A); Z.4-dichlorophenoxyacetic acid (2,4-D); abscisic acid (ABA).
\end{abstract}

Sweetpotato is a root crop of significant agricultural importance internationally (Henderson et al., 1984). Somatic hybridization may be a useful tool for producing new hybrids of sweetpotato where genetic variability is limited among sexually compatible genotypes. Of particular value might be the generation of asymmetric somatic hybrids, where one complete genome is combined at random with only a portion of a second genome (Chatterjee et al., 1988; Dudits et al., 1987; Gleba et al.; 1988).

Plant regeneration from parental protoplasts is one prerequisite for the production of somatic hybrid plants. Only a few reports are available on protoplasm isolation and culture of sweetpotato. Protoplasts from stems (Wu and Ma, 1979), petioles (Bidney and Shepard, 1980; Sihachakr and Ducreux, 1986), and leaves (Otani et al., 1987) have been shown to undergo division and callus formation. Plants have been regenerated from petiole protoplasts of 'Chugoku no. 25' (Murata et al., 1987) and stem and petiole protoplasts of cultivar Duclos XI (Sihachakr and Ducreux, 1987).

One problem encountered in production of somatic hybrids through protoplasm fusion is distinguishing between fusion products and unfused parental protoplasts. Many selection schemes for heterokaryons have been developed (see reviews by Evans, 1983; Harms, 1983; Schieder, 1980). Application of flow cytometry to sort heterokaryons has a major advantage over most other techniques because it does not depend on the presence of known genetic markers in parental populations. Alexander et al. (1985) were able to successfully sort heterokaryons from

Received for publication 1 Oct. 1990. Funding provided by the Georgia Agricultural Experiment Stations. We gratefully acknowledge Julie Golden for assistance with flow cytometry, Kaine Bondari for assistance with statistical analyses and Mel Hall for providing plant material. The cost of publishing this paper was defrayed in part by the payment of page charges. Under postal regulations, this paper therefore must be hereby marked advertisement solely to indicate this fact.
Hordeum vulgare L. and Datura innoxia Mill. fusion mixtures. Puite et al. (1988) showed that inhibition of cell wall synthesis using DB can improve the recovery of intact fusion products after flow-sorting. Regeneration of hybrids that were selected by flow-sorting has been reported for Nicotiana tabacum L., N. sylvestris Speg. \& Comes, N. nesophyla Johnston, and N. stocktonii Brandegee (Afonso et al., 1985), Brassica oleracea L. and B. campestris L. (Glimelius et al., 1986), and Solarium tuberosum L. and S. phureja Juz et Buk (Puite et al., 1988). We are attempting to develop a generally applicable method for the selection and/or enrichment of asymmetric somatic hybrids using flow cytometry. This method involves gamma irradiation of one parental protoplasm population to prevent cell division, followed by staining of the irradiated protoplasts with a fluorescent dye to allow discrimination of three populations: nonfluorescent, nonirradiated parental protoplasts; fluorescent, irradiated parental protoplasts; and fluorescent heterokaryons. Only the nondividing, irradiated protoplasts and heterokaryons should be sorted out by the flow cytometer due to their fluorescence. Initially, we have examined certain procedures that might be involved in the success of such an approach, including the effect of FDA on protoplasm yield and division and of DB on the cell cycle and protoplasm division. Additional factors that can affect protoplasm yield and survival were investigated, i.e., pretreatment of enzyme solutions with activated charcoal, incorporation of STS in the culture medium of protoplast-donor plants, and culture of protoplasts in liquid or agarose medium. Finally, plant regeneration from protoplasts was extended to two regionally important sweetpotato cultivars, Red Jewel and Georgia Jet.

\section{Materials and Methods}

Protoplasm culture. 'Red Jewel' and 'Georgia Jet' sweetpotatoes were used for protoplasm isolation. Donor plants were maintained in sweetpotato medium (SPM) 3, a modified MS (Murashige and Skoog, 1962) medium containing $4.46 \mathrm{mg}$ 
$\mathrm{MnSO}_{4} \cdot 4 \mathrm{H}_{2} \mathrm{O} / \mathrm{liter}, 0.4 \mathrm{mg}$ thiamine/liter as the sole vitamin, and $1 \%$ agar. Plants were grown in a 16 -h photoperiod at $27 \mathrm{C}$. For protoplasm isolation, petioles were chopped and incubated in enzyme solution $(0.25 \mathrm{~g}$ tissue $/ \mathrm{ml})$ containing either $0.5 \%$ Cellulase Onozuka RS, $0.5 \%$ Macerozyme R-10, $0.05 \%$ Pectolyase Y23, and $0.5 \mathrm{~m}$ mannitol (enzyme 1) or $1 \%$ Cellulase Onozuka RS, $0.1 \%$ Pectolyase Y23, $5 \mathrm{~mm} \mathrm{CaCl}_{2} \cdot 2 \mathrm{H}_{2} \mathrm{O}$, and 0.5 M mannitol (enzyme 2-modified from Murata et al., 1987). Enzyme solutions were filter-sterilized after adjusting the $\mathrm{pH}$ to 5.8 to 6.0. Digestion was carried out in disposable plastic petri dishes (darkness, 27C) with gentle swirling (30 to $35 \mathrm{rpm}$ ) for 4 to $5 \mathrm{~h}$. The crude protoplasm Suspension was filtered through Miracloth (Calbiochem, La Jolla, Calif.) and centrifuged at $200 \times$ $\mathrm{g}$ for $5 \mathrm{~min}$. Pelleted protoplasts were washed once with W5 solution (Menczel and Wolfe, 1984) (154 mM NaCl, $125 \mathrm{mM}$ $\mathrm{CaCl}_{2}, 5 \mathrm{~mm} \mathrm{KCl}, 5 \mathrm{~mm}$ glucose, $\mathrm{pH}$ 5.6, 620 milliosmol before floating on $20 \%$ sucrose $(200 \times \mathrm{g}, 10$ rein). Floating protoplasts were washed again with culture medium containing Kao and Michayluk (1975) basal salts, $0.5 \mathrm{M}$ glucose, $1 \mathrm{mg}$ 2,4-D/liter, and $1 \mathrm{mg}$ 6-benzylaminopurine (BAP)/liter (hereafter called KM2 medium). The final pellet was resuspended in KM2 medium and cultured in $60-\mathrm{mm}$ plastic petri plates, sealed with parafilm, $2 \mathrm{ml} /$ plate at a density of 1 to $5 \times 10^{5}$ protoplasts/ml. Cultures were incubated in the dark at $27 \mathrm{C}$.

After 2 to 3 weeks in culture, actively dividing protoplastderived colonies were diluted with $0.5 \mathrm{ml}$ of $\mathrm{KM} 2$ medium containing $0.3 \mathrm{M}$ instead of $0.5 \mathrm{M}$ glucose Four weeks later, cultures were solidified by the addition of $2 \mathrm{ml}$ of KM2 medium with $0.3 \mathrm{M}$ glucose and $0.8 \%$ SeaPlaque agarose (FMC BioProducts, Rockland, Maine) at 37C. Small calli that formed on the agarose medium were transferred to either MS Al [from Murata et al., 1987; $\mathrm{MS}$ with $\mathrm{NH}_{4} \mathrm{NO}_{3}$ and $\mathrm{KNO}_{3}$ reduced to 800 and $1400 \mathrm{mg} \cdot$ liter $^{-1}$, respectively, plus (in mg.liter ${ }^{-1}$ ) 0.5 2,4-D, 0.5 kinetin, 1.0 ABA, and $0.8 \%$ agar], MS A2 (same $\mathrm{N}$ content as MS Al plus $2.0 \mathrm{mg} 2,4-\mathrm{D} /$ liter and $50 \mathrm{ml}$ coconut milliliter), or MS A3 (MS plus $1.0 \mathrm{mg} 2,4-\mathrm{D} / \mathrm{liter}$ and $1.0 \mathrm{mg}$ $\mathrm{BAP} / \mathrm{liter}$ ) for further growth. Calli were transferred for regeneration as indicated in the next section. Rooted plantlets first were transplanted into sand in a mist bench and later transferred into pots containing a peat-vermiculite potting mix.

Various treatments were tested for their effect on yield, viability, and division frequency of 'Red Jewel' protoplasts. Protoplasm yield was determined by counting an aliquot of protoplasm suspension after dilution in culture medium. Viability was assayed by staining with FDA at a final concentration of $4 \mu \mathrm{g}-\mathrm{ml}^{-1}$ in the enzyme solution (Widholm, 1972). Division frequency was measured after 1 week in culture. The following experiments were conducted: 1) Enzyme solutions pretreated with $1 \%$ activated charcoal (R. Hauptmann, personal communication) were compared with untreated enzyme solutions. Activated charcoal (1\%) was added to enzyme solutions, stirred for 30 rein, and removed by filtering through a $0.45-\mu \mathrm{m}$ filter. 2) The effect of STS on plant growth and protoplasm yield was determined by growing donor plants for one passage in SPM 3 medium containing $2 \mathrm{mg} \mathrm{STS} / \mathrm{liter}$. Four weeks after culture, shoot and root fresh weights were measured and material was used for protoplasm isolation. 3) Protoplasts were cultured in liquid and semisolid (0.4\% SeaPlaque agarose) KM2 medium.

Organogenesis in protoplasm-derived callus. 'Georgia Jet' was used more extensively for regeneration experiments than 'Red Jewel'. Calli growing on the three maintenance media (MS Al, MS A2, and MS A3) were transferred for one or more passages on agar-solidified media K1 (MS + $1.0 \mathrm{mg}$ kinetin/liter), B1
(0.5 mg BAP/liter), 11 [MS + $0.2 \mathrm{mg}$ indole-3-butyric acid (IBA)/liter], or $\mathrm{T} 1$ (MS $+0.5 \mathrm{mg}$ thiamine/liter). Root and shoot formation on these media and subsequent basal MS media solidified with $0.2 \%$ Gelrite and containing varying sucrose concentrations was recorded. Shoots produced from both cultivars were transferred to SPM 3 medium to induce rooting. Regenerated roots from callus of 'Georgia Jet' were cut into $1-\mathrm{cm}$ long pieces and cultured on MS medium containing $0.02 \mathrm{mg}$ kinetin/liter, $0.2 \%$ Gelrite, and either $6 \%$ fructose or $2 \%$ sucrose to induce adventitious shoot formation.

Effect of FDA and DB on protoplasts. To study the effect of inhibition of cell wall formation on the cell cycle and cell division, protoplasts were cultured $24 \mathrm{~h}$ in KM2 medium containing $2 \mu \mathrm{g} \mathrm{DB} / \mathrm{ml}$ to simulate the conditions of a fusion and flow-sorting experiment. DB was removed by centrifugation $(200 \times \mathrm{g}, 5 \mathrm{~min})$, and the protoplasts were-cultured in KM2 without DB. Division frequency was determined 1 week later.

The effect of DB on the cell cycle was determined by analyzing the nuclear DNA content of protoplasts cultured in the presence or absence of DB for $24 \mathrm{~h}$. Nuclei were isolated after $24 \mathrm{~h}$ for cell cycle analysis. The distribution of cells in various phases of the cell cycle also was determined in chopped petioles and freshly isolated protoplasts. Fresh tissues or pelleted protoplasts were resuspended in Dolezel et al.'s (1989) LB01 buffer containing $15 \mathrm{~mm}$ Tris ( $\mathrm{pH}$ 7.5), $2 \mathrm{~mm} \mathrm{Na} \mathrm{N}_{2}$ EDTA, $0.5 \mathrm{~mm}$ spermidine, $80 \mathrm{~mm} \mathrm{KCl}, 20 \mathrm{~mm} \mathrm{NaCl}, 15 \mathrm{~mm}$ mercaptoethanol, and $1 \%$ Triton $\mathrm{X}-100$, instead of $0.1 \%$ Triton $\mathrm{X}-100$, and held for 15 to $30 \mathrm{~min}$ to release the nuclei. After lysis, the suspension was filtered through a $60-\mu \mathrm{m}$ mesh to remove debris. The filtrate was centrifuged for $5 \mathrm{~min}$ at $700 \times \mathrm{g}$, and the pellet was resuspended in $100 \mu \mathrm{l}$ of buffer containing $10 \mathrm{~mm}$ Tris $(\mathrm{pH}$ 7.5), $10 \mathrm{~mm} \mathrm{Na}$ EDTA, $100 \mathrm{~mm} \mathrm{NaCl} \mathrm{(pH} \mathrm{7.4),} \mathrm{and} 0.1 \%$ Triton X-100 (Sgorbati et al., 1988). Nuclei were fixed for 15 to $30 \mathrm{~min}$ by adding $1 \mathrm{ml}$ of $10.9 \% \mathrm{NaCl}: 1$ ethanol $(\mathrm{v} / \mathrm{v})$ (Hulgenhof et al., 1988) to the resuspended nuclei. Nuclei were pelleted as above, resuspended in $96 \%$ ethanol, and stored at $4 \mathrm{C}$.

The nuclei were prepared for flow cytometry by brief centrifugation and resuspension in $400 \mu \mathrm{l}$ Tris buffer (Sgorbati et al., 1988) containing $2 \mu \mathrm{g}$ 4,6-diamidino-2-phenylindole (DAPI)/ liter. After 15 to $30 \mathrm{~min}$, the preparation was filtered through a $10-\mu \mathrm{m}$ mesh, and DNA content was analyzed with a EPICF 753 flow cytometer (Coulter Corp., Hialeah, Fla.). The excitation was in the UV range. Fluorescence was collected by a 418-nm-long pass filter. Cell cycle of isolated nuclei was analyzed by PARA 1 (Coulter, EASY 88 Data Management System, Product Reference Manual, Apr. 1986), a program designed to perform cell cycle analysis of asynchronous cell populations.

The possible effect of FDA staining on protoplasm viability was tested by including $4 \mu \mathrm{g} \mathrm{FDA} / \mathrm{ml}$ in the enzyme solution. The total yield of protoplasts was measured at the time of culture, and division frequency was determined after 7 days in culture.

Design of experiment and statistical analysis. The effects of charcoal pretreatment of enzyme solutions and of culture of protoplast-donor plants in STS-containing medium on yield and viability of protoplasts were tested using a completely randomized design. Two experiments, each with 10 replicates, were conducted. The means were compared using Student's $t$ test at $\boldsymbol{P}=0.05$.

Various factors that influence division frequency were tested under a completely randomized design. Some experiments had four replicates (culture of protoplasts in liquid or solid medium 
and pretreatment of enzymes with charcoal) and the others had six (culture of protoplast-donor plants in STS-containing medium and staining protoplasts with FDA). Student's $\boldsymbol{t}$ test was conducted at $\boldsymbol{P}=0.05$ after arcsin transformation to, account for percentage nature of the data.

The cell cycle of sweetpotato petioles and protoplasts was analyzed using six and four replicates, respectively. Analysis of variance was conducted at $\boldsymbol{P}=0.05$. After confirming the significance of the $\mathrm{F}$ value, further mean separations were done by Duncan's multiple range test at $\boldsymbol{P}=0.05$.

\section{Results}

Sweetpotato protoplasm isolation and callus formation. Both enzyme 1 and enzyme 2 were effective in producing a protoplasm yield of $1 \times 10^{5}$ to $1 \times 10^{6} / \mathrm{g}$ from 'Georgia Jet' and 'Red Jewel'. Preliminary experiments showed that petioles gave a cleaner protoplasm preparation than mesophyll tissue. Cell wall formation of the petiole protoplasts occurred within $24 \mathrm{~h}$ and cell division was initiated in 2 to 3 days. About 10 to 12 weeks after culture, the individual colonies were large enough to be transferred onto MS A1, MS A2, and MS A3 media for proliferation of callus. Callus grew profusely in all three media tested. The calli of both cultivars were friable and yellow to orange.

Addition of STS to the culture medium of donor plants did not influence the fresh weight of plants. The mean fresh weight of plants was $5.61 \pm 1.59$ with STS and $5.44 \pm 0.93 \mathrm{~g}$ without STS, as determined from two experiments, each with eight replicates. Neither culture of protoplasm-donor plants on STS-containing medium nor charcoal pretreatment of the enzyme affected protoplasm yield; however, charcoal pretreatment significantly increased protoplasm viability (Table 1). Several factors had a significant effect on division frequency, including enzyme pretreatment, growth of donor plants on STS, and culture of protoplasts on agarose vs. liquid medium (Table 2). Addition of DB to the culture medium or staining protoplasts with FDA did not -affect the ability of protoplasts to divide in culture (Table 2 ). A large variation in the division frequency of protoplasts was observed with different treatments in different experiments, with values ranging from $1.86 \%$ to $9.51 \%$.

In freshly isolated protoplasts and protoplasts cultured with or without DB for $24 \mathrm{~h}$, most nuclei were in the $\mathrm{G}_{1}$ phase (Table 3 ). The percentage of $G_{1}$ nuclei in the petioles was significantly lower than that in fresh protoplasts and protoplasts cultured for $24 \mathrm{~h}$ in the presence or absence of DB. Conversely, a significantly higher percentage of petiole nuclei was in the $G_{2}$ phase.

Plant regeneration. 'Red Jewel' tissues that had been transferred from maintenance medium MS Al to $\mathrm{Kl}$, followed by $\mathrm{Tl}$, followed by $\mathrm{MS}+3 \%$ sucrose $+0.2 \%$ Gelrite produced a single cluster of shoots from one callus and roots from several

Table 1. Effect of charcoal pretreatment of enzyme and culture of donor plants with or without STS in medium on the yield and viability of 'Red Jewel' sweetpotato protoplasts. Viability is measured as the percentage of protoplasts stained with FDA at time of culture. ${ }^{2}$

\begin{tabular}{lcc}
\hline \hline Treatment & $\begin{array}{c}\text { Yield } \\
\left(\times 10^{5} / \mathrm{g}\right)\end{array}$ & Viability \\
\hline Charcoal & $5.45 \pm 0.46^{\mathrm{NS}}$ & $98.3 \% \pm 1.36 \%^{*}$ \\
No charcoal & $5.34 \pm 0.85^{\mathrm{NS}}$ & $76.8 \% \pm 4.89 \%^{*}$ \\
With STS & $3.50 \pm 0.54^{\mathrm{NS}}$ & $68.6 \% \pm 5.18 \%^{\mathrm{NS}}$ \\
Without STS & $4.08 \pm 0.79^{\mathrm{NS}}$ & $71.9 \% \pm 5.07 \% \mathrm{NS}$ \\
\hline
\end{tabular}

${ }^{2}$ Data are means of 20 replications, 10 replicate counts from two experiments.

${ }_{*, N S}$ Significant at $P=0.05$ or not significant, respectively.
Table 2. Effect of various factors on the division frequency of 'Red Jewel' sweetpotato protoplasts. Division frequency is given as percentage of protoplasts cultured that are dividing after 7 days \pm SD.

\begin{tabular}{ll}
\hline Treatment & Division frequencyz \\
\hline Medium & \\
$\quad$ Agarose & $6.59 \% \pm 0.33 \%^{*}$ \\
$\quad$ Liquid & $9.51 \% \pm 0.76 \%^{*}$ \\
Pretreatment of enzyme & \\
$\quad$ Charcoal & $5.82 \% \pm 0.38 \%^{*}$ \\
$\quad$ No charcoal & $1.86 \% \pm 0.59 \%^{*}$ \\
Medium content & \\
$\quad$ STS & $9.19 \% \pm 1.36 \%^{*}$ \\
$\quad$ No STS & $6.59 \% \pm 0.33 \%^{*}$ \\
Protoplast staining & \\
$\quad$ Stained with FDA & $3.78 \% \pm 0.34 \%^{\mathrm{NS}}$ \\
$\quad$ Not stained with FDA & $3.56 \% \pm 0.25 \% \%^{\mathrm{NS}}$ \\
Protoplast culture & \\
$\quad 24$ h with DB & $2.92 \% \pm 0.72 \% \mathrm{NS}$ \\
$\quad$ Without DB & $3.14 \% \pm 0.65 \%^{\mathrm{NS}}$ \\
\hline
\end{tabular}

${ }^{2}$ Values given for each comparison are the means of four to six replicates from two consecutive experiments.

*,Ns Significant at $P=0.05$ or not significant, respectively.

Table 3. Cell cycle analysis of 'Red Jewel' sweetpotato petioles, freshly isolated protoplasts, and protoplasts cultured with or without DB for $24 \mathrm{~h}$.

\begin{tabular}{lcccc}
\hline & \multicolumn{2}{c}{ Cells in cycle indicated (\%) } & \multicolumn{2}{c}{$\begin{array}{c}\text { CV range } \\
\text { for G1 peak }\end{array}$} \\
\cline { 2 - 5 } Tissue & $\mathrm{G} 1$ & $\mathrm{~S}$ & $\mathrm{G} 2$ & $(\%)$ \\
\hline $\begin{array}{l}\text { Petioles } \\
\begin{array}{l}\text { Freshly isolated } \\
\quad \text { protoplasts }\end{array}\end{array}$ & $38.7 \mathrm{~b}$ & $31.1 \mathrm{a}$ & $30.2 \mathrm{a}$ & $6.31-12.3$ \\
$\begin{array}{l}\text { Protoplasts } \\
\quad \text { cultured without DB }\end{array}$ & $53.5 \mathrm{a}$ & $32.4 \mathrm{a}$ & $14.1 \mathrm{~b}$ & $5.33-9.56$ \\
$\begin{array}{l}\text { Protoplasts } \\
\quad \text { cultured with DB }\end{array}$ & $50.2 \mathrm{a}$ & $37.6 \mathrm{a}$ & $12.2 \mathrm{~b}$ & $8.74-17.8$ \\
\hline
\end{tabular}

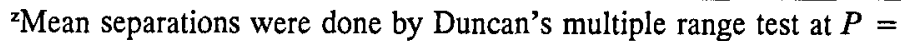
0.05 , values given are the means of four to six replicates.

calli. Roots also were formed after the media sequence: MS Al, followed by $\mathrm{B} 1$ or 11 , followed by $\mathrm{Tl}$, followed by $\mathrm{MS}+3 \%$ sucrose $+0.2 \%$ Gelrite. The callus that produced shoot initials was periodically subculture in SPM 3 medium and continued to produce shoots for 10 months. Shoots were rooted on SPM 3 medium. All survived when plants were transplanted to peatvermiculite potting mix in the greenhouse.

Since callus morphology on K1 was more indicative of organogenic callus (green and hard vs. orange to white and friable), B1 and I1 were not included in organogenesis experiments with 'Georgia Jet'. Compact green callus of 'Georgia Jet' was formed on $\mathrm{K} 1$ and transferred for several additional passages to $\mathrm{Kl}$, while friable yellow callus was transferred to T1 medium. The first shoot bud appeared 10 weeks after initial transfer to $\mathrm{Kl}$, but only in the media sequence that previously included a transfer on maintenance medium MS Al. The frequency of shoot formation during that passage was $6.6 \%$ (based on the number of calli forming shoots per total number of calli). Root formation from callus on $\mathrm{K} 1$ occurred after $\approx 19$ weeks with $11 \%$ frequency and included callus previously cultured on MS Al, MS A2, and MS A3. Callus maintained on K1 medium continued to form roots. Figures $1 \mathrm{a}$ and $\mathrm{b}$ show examples of shoot and root regeneration from callus. A few more shoots $(6.4 \%$ frequency) and many roots ( $46.2 \%$ frequency) were formed after transfer to regular MS medium containing 3\% sucrose and $0.2 \%$ 


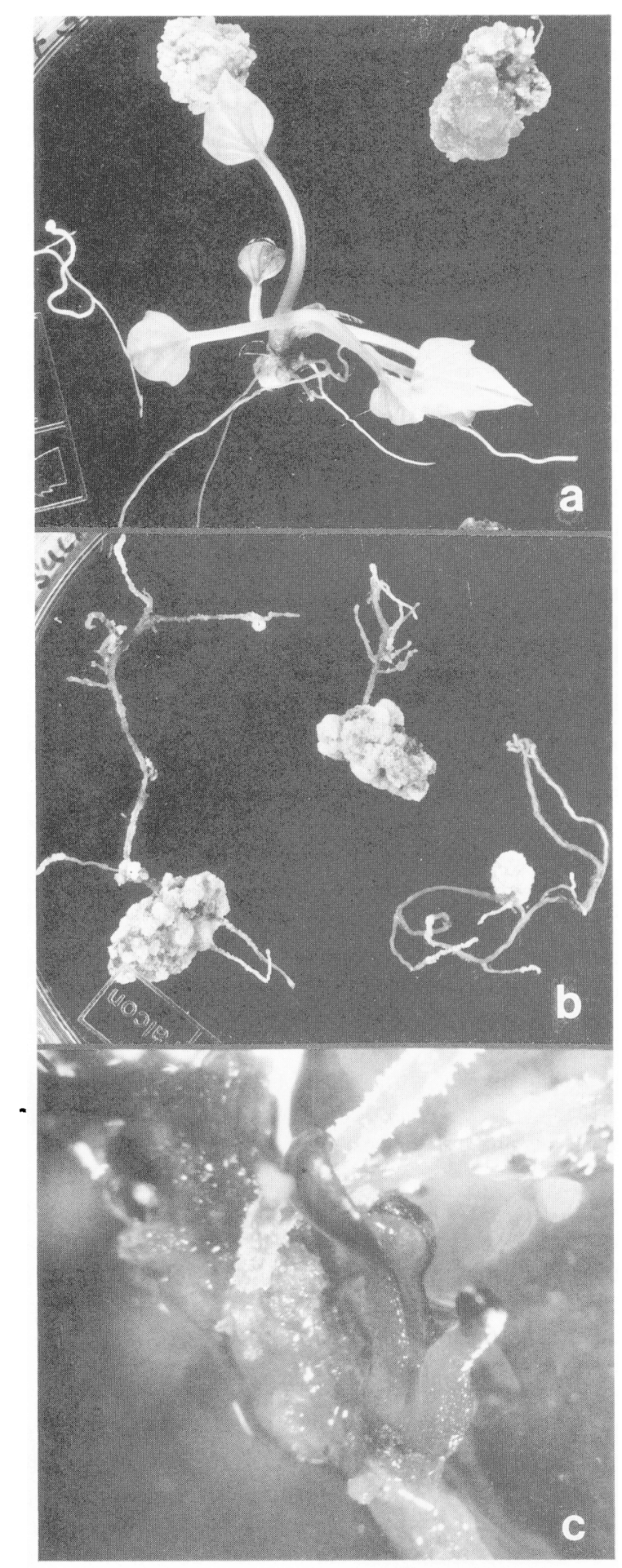

Fig. 1. (a) Shoot formation from callus. (b) Root formation from callus. (c) Shoot bud formation from protoplast-derived roots.

Gelrite. Shoots were rooted on SPM 3 medium. Callus on T1 medium started to turn brown and degenerate. However, when the still-viable callus on T1 was transferred into MS medium containing $3 \%$ sucrose and $0.2 \%$ Gelrite, a few roots $(13.3 \%$ frequency) were obtained.

An alternative method for shoot regeneration from 'Georgia Jet' also was successful. To induce shoot formation from roots, callus-derived roots were cut into $1-\mathrm{cm}$-long pieces and cultured in MS medium containing $0.02 \mathrm{mg}$ kinetin/liter, $0.2 \%$ Gelrite, and either $6 \%$ fructose or $2 \%$ sucrose. Roots in fructose-containing medium continued to elongate, swell, and form callus. Some roots continued to grow and form laterals in both media. Shoot buds formed in sucrose-containing medium after 4 weeks (Fig. 1c). About 10\% of the cultured root segments formed shoots in any one passage.

\section{Discussion}

Isolation of protoplasts from petioles of 'Red Jewel' and Georgia Jet' sweetpotato using two different enzyme solutions was possible. Cell wall formation was observed within $24 \mathrm{~h}$. This finding is consistent with the results of Bidney and Shepard (1980), who reported that cell wall formation occurred in 24 to $48 \mathrm{~h}$. According to them, Wu and Ma (1979), and Murata et al. (1987), the first cell division of sweetpotato protoplasts occurred after 6, 10, and 12 days, respectively. However, -in our study the first division occurred as early as 2 to 3 days after culture. Early division could be due to the use of more complex culture medium (KM) in this study instead of MS medium.

The division frequency of protoplasts after 7 days in culture was between $2 \%$ and $10 \%$. Bidney and Shepard (1980) reported a high plating efficiency of $60 \%$ and $70 \%$ for protoplasts of 'Jewel' and 'Centennial', respectively. A different method of computation may have been used to determine plating efficiency in their study.

Pretreatment of enzyme solutions with activated charcoal significantly increased the protoplasm viability and division but not the actual yield of protoplasts. Perl et al. (1988) reported that Solanum tuberosum plants-grown in the presence of STS produced more shoots and roots than without STS. In addition, plants grown in STS-containing medium yielded three times more protoplasts per unit mass of tissue than those grown in the absence of STS. We failed to obtain similar results with sweetpotato. In our study, STS did not affect the growth of 'Red Jewel' plants or yield and viability of protoplasts. However, there was a significant increase in the division of protoplasts isolated from plants grown in the presence of STS. Division frequency of protoplasts cultured in liquid medium was significantly higher than that of protoplasts cultured in solid medium. Protoplasm division was not affected by FDA staining or culture of protoplasts in the presence of DB for $24 \mathrm{~h}$.

As revealed by cell cycle analysis, the nuclei of petioles, freshly isolated protoplasts, and protoplasts cultured with or without DB for $24 \mathrm{~h}$ were in various phases of the cell cycle. Dolezel et al. (1989) reported that most nuclei isolated from leaf tissue of Medicago sativa L., Zea mays L., Allium sativum L., and Vitis vinifera $\mathrm{L}$. were in the $\mathrm{G}_{1}$ phase. We failed to make the same observation with chopped sweetpotato petioles, where we obtained $39 \%, 31 \%$, and $30 \%$ nuclei in $\mathrm{G}_{1}, \mathrm{~S}$, and $\mathrm{G}_{2}$ phases, respectively. The percentage of petiole nuclei in $\mathrm{G}_{2}$ phase was significantly higher than that in freshly isolated protoplasts, possibly because only a subset of cells are selected during enzyme digestion and subsequent isolation of protoplasts.

Based on cell cycle analysis of protoplasts derived from rapidly dividing suspension cultures of tobacco, Galbraith (1984) reported that $\mathrm{G}_{1}, \mathrm{~S}$, and $\mathrm{G}_{2}$ phases occupy $57.2 \%, 12.9 \%$, and $29.9 \%$ of the cell cycle. Our study shows a similar $\mathrm{G}_{1}$ value (54\%) for freshly isolated protoplasts. In freshly isolated malefertile and male-sterile Petunia hybrids protoplasts, Bergounioux et al. (1986) observed a large $\mathrm{G}_{1}$ phase $(95 \%)$ and a small $\mathrm{S}+\mathrm{G}_{2}$ phase $(5 \%)$. After $24 \mathrm{~h}$ in culture, cells from the malefertile line in $\mathrm{G}_{1}$ phase decreased to $83 \%$. In our experiments, 
there was no significant difference in the $G_{1}, S$, and $G_{2}$ phases of freshly isolated protoplasts and protoplasts cultured for $24 \mathrm{~h}$, indicating that a majority of protoplasts had not initiated DNA synthesis or entered mitosis after $24 \mathrm{~h}$.

The $G_{1}, S$, and $G_{2}$ values of protoplasts cultured in the presence of DB were not significantly different from those of protoplasts cultured without DB. The presence of DB in the culture medium did not affect the cell cycle. Galbraith and Shields (1982) reported that DB does not have an inhibitory effect on DNA synthesis or mitosis of tobacco protoplasts. According to their results, DNA synthesis of protoplasts cultured with DB was initiated immediately in culture, but mitosis was not observed until after 2 days. In our experiments, we did hot observe initiation of DNA synthesis or mitosis after $24 \mathrm{~h}$ in DB.

Bidney and Shepard (1980) obtained callus formation from sweetpotato protoplasts in ammonium-free medium. Murata et al. (1987) tested various media containing $800 \mathrm{mg} \mathrm{NH}_{4} \mathrm{NO}_{3} /$ liter and $1400 \mathrm{mg} \mathrm{KNO}_{3} /$ liter and various concentrations of growth regulators. Although callus growth was observed to some degree in all these media, only callus on one medium (designated MS Al in our experiments) underwent shoot morphogenesis when transferred to regeneration medium. We tested MS Al and two other media for callus growth from 'Georgia Jet' protoplasts and observed profuse callus growth in all three media, but in accordance with Murata et al. (1987), shoot formation was observed only in callus previously cultured. on MS Al. This response may be due to the presence of ABA in MS Al medium. ABA has previously been shown to induce adventitious shoot formation in callus derived from sweetpotato storage root explants (Yamaguchi and Nakajima, 1972). Murata et al. (1987) reported shoot formation in MS medium containing $1 \mathrm{mg} \mathrm{ki-}$ netin/liter. In our study, when callus was transferred to MS medium containing $1 \mathrm{mg}$ kinetin/liter $(\mathrm{Kl})$, it greened and hardened. 'Georgia Jet' callus formed a few shoots on K1 medium. Both 'Georgia Jet' and 'Red Jewel' formed shoots when callus in $\mathrm{K} 1$ medium was transferred to MS medium containing $0.2 \%$ Gelrite but no growth regulators. In our study, only the compact green calli gave rise to shoots and roots. Sihachakr and Ducreux (1987) also reported the hardening and greening of protoplastderived 'Duclos XI' sweetpotato callus before plant regeneration.

Although shoot formation was sporadic for both 'Red Jewel' and 'Georgia Jet' callus, formation of roots was more frequent. In both cultivars, root formation was observed in almost all the media tested. In vitro shoot bud formation in excised root segments has been reported in Limnophila indica L. (Rao and Mohan Ram, 1981), Brassica oleracea and B. napus L. (Lazzeri and Dunwell, 1984a, 1984b; Lillo and Shahin, 1986), Solarium tuberosum (Espinoza and Dodds, 1985), and Rudbeckia laciniata L. (Al-Atabee et al., 1990). Adventitious roots growing from cultured leaf explants of sweetpotato will spontaneously form buds in vitro (Templeton-Somers and Collins, 1986). We have found that up to 0.5 shoots/root segment can be obtained in MS medium containing 6\% fructose and $0.02 \mathrm{mg}$ kinetin/ liter (P.O., unpublished results with Univ. of Georgia clone 117). A low concentration of sucrose (1\%) also promoted shoot induction. This result was applied in an attempt to induce shoots from protoplast-derived roots. Shoot buds were formed in MS medium containing $0.02 \mathrm{mg}$ kinetin/liter and $2 \%$ sucrose 4 weeks after culture of root segments. Due to the limited number of shoots regenerated directly from protoplast-derived callus, sec- ondary shoot formation from regenerated roots will allow the recovery of more regenerated plants.

\section{Literature Cited}

Afonso, C. L., K.R. Harkins, M.A. Thomas-Compton, A.E. Krejci, and D.W. Galbraith. 1985. Selection of somatic hybrid plants in Nicotiana through fluorescence activated sorting of protoplasts. Bio/Technology. 3:811-816.

Al-Atabee, J. S., B.J. Mulligan, and J.B. Power. 1990. Interspecific somatic hybrids of Rudbeckia hirta and R. laciniata (Composite). Plant Cell Rpt. 8:517-520.

Alexander, R. G., E.C. Cocking, P.J. Jackson, and J.H. Jett. 1985. The characterization and isolation of plant heterokaryons by flow cytometry. Protoplasm 128:52-58.

Bergounioux, C., C. Perennes, C. Miege, and P. Gadal. 1986. The effect of male sterility on protoplasm division in Petunia hybrida. Cell cycle comparison by flow cytometry. Protoplasm 130:138-144.

Bidney, D.L. and J.F. Shepard. 1980. Colony development from sweet potato petiole protoplasts and mesophyll cells. Plant Sci. Lett. 18:335342.

Chatterjee, G., S.R. Sikdar, S. Das, and S.K. Sen. 1988. Intergeneric somatic hybrid production through protoplasm fusion between Brassica juncea and Diplotaxis muralis. Theoretical Applied Genet. 76:915-922.

Dolezel, J., P. Binarova, and S. Lucretti. 1989. Analysis of nuclear DNA content in plant cells by flow cytometry. Biol. Plant. 31(2):113-120.

Dudits, D., E, Maroy, T. Praznovsky, Z. Olah, J. Gyorgyey, and R. Cells. 1987. Transfer of resistance traits from carrot into tobacco by asymmetric somatic hybridization: Regeneration of fertile plants. Proc. Natl. Acad. Sci. USA. 84:8434-8438.

Espinoza, N.O. and J.H. Dodds. 1985. Adventitious shoot formation on cultured potato roots. Plant Sci. 41:121-124.

Evans, D.A. 1983. Protoplasm fusion, p. 291-321. In: D.A. Evans, W.R. Sharp, P.V. Ammirato, and Y. Yamada (eds.). Handbook of plant cell culture. vol. 1. Macmillan, New York.

Galbraith, D.W. 1984. F1ow cytometric analysis of the cell cycle, p. 765-777. In: I.K. Vasil (cd.). Cell culture and somatic cell genetics of plants. vol. 1. Academic, New York.

Galbraith, D.W. and B.A. Shields. 1982. The effects of inhibitors of cell wall synthesis on tobacco protoplast development. Physiol. Plant. 55:25-30.

Gleba, Y. Y., S. Hinnisdaels, V.A. Sidorov, V.A. Kaleda, A.S. Parokanny, N.V. Boryshuk, N.N. Cherep, I. Negrutiu, and M. Jacobs. 1988. Intergeneric asymmetric hybrids between Nicotiana plumbaginifolia and Atropa belladona obtained by "gamma-fusion". Theoretical Applied Genet. 76:760-766.

Glimelius, K., M. Djupsjobacka, and H. Fellner-Feldegg. 1986. Selection and enrichment of plant protoplasm heterokaryons of Brassicaceae by flow sorting. Plant Sci. 45: 133-141.

Harms, C.T. 1983. Somatic hybridization by plant protoplasm fusion, p. 69-84. In: I. Potrykus, C.T. Harms, A. Hinnen, R. Hutter, P.J. King, and R.D. Shillito (eds.). Protoplasts 1983. 6th Intl. Protoplasm Symp., Basal. Birkhauser Verlag, Basel.

Henderson, J. H. M., B.R. Phillis, and B.T. Whatley. 1984. Sweet potato, p. 302-326. In: W.R. Sharp, D.A. Evans, P.V. Ammirato, and Y. Yamada (eds.). Handbook of plant cell culture, crop species. Macmillan, New York.

Hulgenhof, E., R.A. Weidhase, R. Schlegel, and A. Tewes. 1988. Flow cytometric determination of DNA content in isolated nuclei of cereals. Genome 30:565-569.

Kao, K.N. and M.R. Michayluk. 1975. Nutritional requirements for growth of Vicia hajastana cells and protoplasts at a very low population density in liquid media. Planta 126:105-110.

Lazzeri, P.A. and J.M. Dunwell. 1984a. Establishment of isolated root cultures of Brussica species and regeneration from cultured-root segments of Brassica oleracea var. italica. Ann. Bet. 54:351-361.

Lazzeri, P.A. and J.M. Dunwell. 1984b. In vitro shoot regeneration 
from seedling root segments of Brassica oleracea and Brassica napus cultivars. Ann. Bet. 54:341-350.

Lillo, C. and E.A. Shahin. 1986. Rapid regeneration of plants from hypocotyl protoplasts and root segments of cabbage. HortScience 21:315-317.

Menczel, L. and K. Wolfe. 1984. High frequency of fusion induced in freely suspended protoplasm mixtures by polyethylene glycol and dimethylsulfoxide at high pH. Plant Cell Rpt. 3:196-198.

Murashige, T. and F. Skoog. 1962. A revised medium for rapid growth and bioassays with tobacco tissue cultures. Physiol. Plant. 15:473497.

Murata, T., K. Hoshino, and Y. Miyaji. 1987. Callus formation and plant regeneration from petiole protoplasm of sweet potato, Ipomoea batatas (L.) Lam. Jpn. J. Breeding 37(3):291-298.

Otani, M., T. Shimada, and H. Niizeki. 1987. Mesophyll protoplasm culture of sweet potato (Ipomoea batatas L.). Plant Sci. 53:157-160.

Perl, A., D. Aviv, and E. Galun. 1988. Ethylene and in vitro culture of potato: Suppression of ethylene generation vastly improves protoplasm yield, plating efficiency and transient expression of an alien gene. Plant Cell Rpt. 7:403-406.

Puite, K., W. Ten Broeke, and J. Schaart. 1988. Inhibition of cell wall synthesis improves flow cytometric sorting of potato heterofusions resulting in hybrid plants. Plant Sci. 56:61-68.

Rae, S. and H.Y. Mohan Ram. 1981. Regeneration of whole plants from cultured root tips of Limnophila indica. Can. J. Bot. 59:969973.

Schieder, O. 1980. Somatic hybrids between herbaceous and two tree Datura species. Z. Pflanzenphysiol. 98:119-127.

Sgorbati, S., E. Sparvoli, M. Levi, D. Chiatante, and P. Giordano. 1988. Bivariate cytoflourimetric analysis of DNA and nuclear protein content in plant tissue. Protoplasm 144:180-184.

Sihachakr, D. and G. Ducreux. 1986. Isolement et culture de protoplastes a partir de petioles et de tiges de deux varietes de patate deuce (Ipomoea batatas). Can. J. Bet. 65:192-197.

Sihachakr, D. and G. Ducreux. 1987. Plant regeneration from protoplasm culture of sweet potato (Ipomoea butatas Lam.). Plant Cell Rpt. 6:326-328.

Templeton-Somers, K.M. and W.W. Collins. 1986. Field performance and clonal variability in sweet potatoes propagated in vitro. J. Amer. Soc. Hort. Sci. 111:689-694.

Widholm, J.M. 1972. The use of fluorescein diacetate and phenosafranine for determining viability of cultured plant cells. Stain Technol. 47:189-194.

Wu, Y. and C. Ma. 1979. Isolation, culture and callus formation of Ipomoea batatas protoplasts. Acta Bet. Sin. 21(4):334-338.

Yamaguchi, T. and T. Nakajima. 1972. Effect of abscisic acid on adventitious bud formation from cultured tissue of sweet potato. Crop Sci. Soc. Jpn. Proc. 41:531-532. 